\title{
Using Static Acoustic Monitoring to Describe Echolocation Behaviour of Heaviside's Dolphins (Cephalorhynchus heavisidii) in Namibia
}

\author{
Ruth H. Leeney, ${ }^{1,2}$ David Carslake, ${ }^{3}$ and Simon H. Elwen ${ }^{2,4}$ \\ ${ }^{1}$ Provincetown Center for Coastal Studies, 5 Holway Avenue, Provincetown, MA 02657, USA \\ ${ }^{2}$ Namibian Dolphin Project, Walvis Bay, Namibia; E-mail: ruleeney@yahoo.co.uk \\ ${ }^{3}$ Department of Biological Sciences, University of Warwick, Gibbet Hill Road, Coventry, CV4 7AL, UK \\ ${ }^{4}$ Mammal Research Institute, Department of Zoology and Entomology, University of Pretoria, Pretoria, 0002, South Africa
}

\begin{abstract}
Static acoustic monitoring is a cost-effective, low-effort means of gathering large datasets on echolocation click characteristics and habitat use by odontocetes. Heaviside's dolphins (Cephalorhynchus heavisidii) were monitored using an acoustic monitoring unit, the T-POD, in July 2008 at a site of known high abundance for this species in Walvis Bay, Namibia. The T-POD successfully detected clicks from Heaviside's dolphins, and these clicks were detected in the 120 to $140 \mathrm{kHz}$ frequency range. A distinct diel pattern to the hourly mean inter-click interval was observed, with higher values during daylight hours than at night, suggesting that click trains are produced at faster rates at night time. There was no apparent diel pattern in the proportion of buzz trains produced, however. A diel pattern in click activity was observed, with many more detection-positive minutes per hour recorded between dusk and dawn, and vocalization activity dropping to low levels in the middle of the day. This corresponded with visual observations made on abundance of dolphins in the study area. These results suggest that Heaviside's dolphins use this site primarily during the night. Static acoustic monitoring proved to be an effective technique for monitoring patterns of habitat use by Heaviside's dolphins.
\end{abstract}

Key Words: habitat use, echolocation behaviour, T-POD, inter-click interval, Heaviside's dolphin, Cephalorhynchus heavisidii, click train

\section{Introduction}

Heaviside's dolphins (Cephalorhynchus heavisidii) are endemic to the Benguela ecosystem of the west coast of southern Africa, inhabiting the coastal and shelf waters of South Africa, Namibia, and southern Angola (Findlay et al., 1992). Little is known about this species in the northern part of its range, with most ecological research to date having concentrated on populations in South Africa, which were shown to be locally abundant and have small home ranges (Elwen et al., 2006, 2009). Like other small coastal delphinids, it faces a number of threats such as coastal development, boat traffic, pollution, prey depletion, and bycatch in fisheries (Best \& Abernethy, 1994; Elwen \& Leeney, 2010). Populations of the congeneric Hector's and Chilean dolphins ( $C$. hectori and C. eutropia) have been severely impacted by near-shore fishing activities (Dawson, 1991; Iñíguez et al., 2003; King \& Brooks, 2004). There is a clear need for more data on the Heaviside's dolphins in Namibian waters and for ongoing monitoring of this population in parts of its range which may face human impacts.

Passive acoustic monitoring (PAM) techniques involve the detection of cetacean vocalizations from either towed or static hydrophones, and this method is increasingly being used to collect data on cetacean habitat use (e.g., Rayment et al., 2009b; Simon et al., 2010), behaviour (e.g., Leeney et al., 2007; Van Parijs et al., 2009; Akamatsu et al., 2010; Clausen et al., 2010; Kyhn et al., 2010), and even to estimate abundance (e.g., Marques et al., 2009; Whitehead, 2009). Static acoustic monitoring (SAM), using moored equipment to detect cetacean vocalizations from a fixed area, enables the observation of trends in relative abundance and of behaviours of target animals within a focal area (Kimura et al., 2010) and has several advantages over visual techniques. Automated data collection can occur around the clock, regardless of sea state or weather conditions (although these factors may somewhat affect detection rates). It thus limits biases related to environmental effects or observer experience, and it produces a detailed dataset incorporating both nocturnal and diurnal activity for relatively little effort or expense in the field (Mellinger et al., 2007). SAM is thus particularly suited to remote 
areas or regions which frequently experience poor weather. The main disadvantage of SAM methods is that at present, for most species, it is not possible to calculate abundance from the resulting data, although recent research has begun to address this issue (Whitehead, 2009; Kimura et al., 2010). SAM also only detects individuals which are actively vocalizing, and only those within the given detection range of the monitoring device (approximately $250 \mathrm{~m}$ detection radius for harbour porpoise on T-POD [Tougaard et al., 2006], and 198 to $239 \mathrm{~m}$ for Hector's dolphins [Rayment et al., 2009a]). The majority of the Namibian coastline is unpopulated, inaccessible by small boat, and highly exposed to wind and swell. SAM thus provides a potential solution to long-term monitoring of inshore dolphin populations in this environment.

The T-POD is a SAM tool which has been used extensively to monitor odontocetes (Leeney \& Tregenza, 2006; Leeney et al., 2007; Philpott et al., 2007; Verfuß et al., 2007; Kyhn et al., 2008; Todd et al., 2009), including Hector's dolphins of New Zealand (Rayment et al., 2009a, 2009b), a species closely related to Heaviside's dolphins. The T-POD is a self-contained, submersible hydrophone and digital processor which recognizes and logs the echolocation clicks made by odontocetes. Todd et al. (2009) provide a description of the T-POD hardware and of the processes of data collection and classification, while numerous studies have reviewed settings and T-POD functionality (e.g., Thomsen et al., 2005; Philpott et al., 2007; Kyhn et al., 2008; Simon et al., 2010). The onboard data logging nature of the T-POD makes it particularly suited to the study of odontocetes, which use narrow-band high frequency (NBHF) echolocation clicks, such as the Phocoenids (for which the instrument was initially designed; Goodson \& Sturtivant, 1996) and members of the Cephalorhynchus genus, as the sampling rate required for real-time recording $(>250 \mathrm{kHz})$ makes long-term recordings unfeasible.

Watkins et al. (1977) reported low-level, pulsed sounds from Heaviside's dolphins at frequencies of $800 \mathrm{~Hz}$ and with a secondary peak in energy at 2 to $5 \mathrm{kHz}$. The limited bandwidth of the recording equipment used $(60 \mathrm{~Hz}$ to $10 \mathrm{kHz})$ meant that the detection of high-frequency click components, since described for other Cephalorhynchus species (e.g., Dawson, 1988), could not be made. More recently, however, Morisaka et al. (2011) collected data on clicks from Heaviside's dolphins in South Africa using a miniature stereo acoustic data logger and an array of three calibrated hydrophones. The clicks of Heaviside's dolphins conform to the model of species using NBHF clicks (Morisaka \& Connor, 2007). Heaviside's dolphin clicks were reported to have a mean centroid frequency of $125 \mathrm{kHz}$ (range 118 to $132 \mathrm{kHz}$ ), click duration of $74 \mu \mathrm{s}$, inter-click intervals ranging from 2 to $113 \mathrm{~ms}$ (Morisaka et al., 2011), and overall characteristics similar to the clicks of other Cephalorhynchus species (Kamminga \& Wiersma, 1982; Dawson \& Thorpe, 1990; Kyhn et al., 2009, 2010; Götz et al., 2010).

This study documents the use of an established SAM device (T-POD) to detect Heaviside's dolphin clicks, to characterise echolocation behaviour by this species, and to describe temporal patterns in habitat use over a short period, at a single site, in Namibia. SAM has never before been used to monitor habitat use or behaviour by this species.

\section{Materials and Methods}

Walvis Bay is a large $(\sim 10 \times 10 \mathrm{~km})$ bay, located approximately midway along the Namibian coastline (Figure 1). The bay is formed by a long sand spit on the western edge ending at Pelican Point ( $\mathrm{S} 22.8700^{\circ}, \mathrm{E} 14.4479^{\circ}$ ), where there is a known concentration area of Heaviside's dolphins (Elwen \& Leeney, 2010). A large commercial harbour in the southeast corner of the bay $(\sim 10 \mathrm{~km}$ distant $)$ supports several pelagic and demersal fishing fleets and a large marine tourism industry consisting of 25 boats, at least some of which operate in the bay on a daily basis (Elwen \& Leeney, 2008).

A single T-POD (POD 313, Version 3) was attached $5 \mathrm{~m}$ below the surface to a temporary mooring approximately $500 \mathrm{~m}$ north of Pelican Point (S $\left.22.8700^{\circ}, \mathrm{E} 14.4479^{\circ}\right)$ in $30 \mathrm{~m}$ of water. The mooring was made up of a large weight,

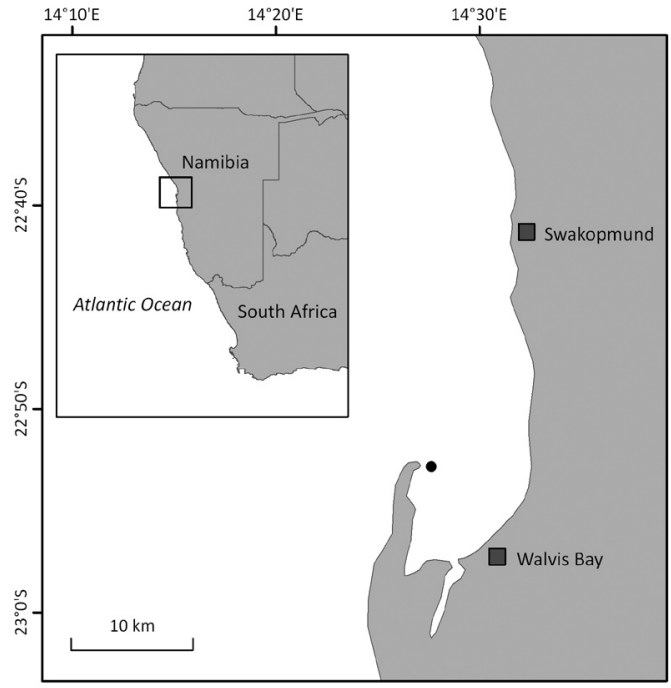

Figure 1. Study location at Walvis Bay, Namibia; the T-POD mooring site at Pelican Point is indicated by the black circle. 
attached by a length of chain to a smaller anchor which could be lifted by hand from the research vessel. A line ran between this anchor and a surface marker buoy. Loops in this line allowed for the attachment of the T-POD at a point $5 \mathrm{~m}$ below the buoy. Data were collected between 28 June and 3 July and 16 to 25 July 2008, amounting to $337 \mathrm{~h}$ of data. The deployment site features a muddy bottom and small tidal range $(1.4 \mathrm{~m}$ at spring tides; South African Naval Hydrographic Office, www.sanho.co.za) with negligible tidal currents. Boat traffic is considerable in the area, mostly comprising small ( 8 to $12 \mathrm{~m}$ ) dolphinwatching boats with outboard engines (90 to $250 \mathrm{hp}$ ). Larger ships entering and exiting the harbour passed at least $2 \mathrm{~km}$ north of the T-POD. Pelican Point is of low elevation and exposed to the strong southerly winds common along the Namibian coast, making it entirely unsuitable for carrying out comparative land-based visual observations around the T-POD.

\section{Data Processing}

The T-POD was initially set to detect clicks in a range of frequencies in order to assess which frequency band was most effective for detecting clicks from Heaviside's dolphins. T-PODs function by comparing the output of the two bandpass filters, A and B (Table 1). The target filter (A) is set to the frequency of the cetacean clicks to be detected, if known; and the reference filter (B) is set to another frequency known to contain the least energy within a click. Target frequencies for 10 -s scans carried out by the T-POD were evenly spaced between 50 and $150 \mathrm{kHz}$. After a 48-h test deployment, the optimal settings for detecting this species were determined to be similar to those which have previously been used for both harbor porpoises and Hector's dolphins (Rayment et al., 2009b; Tougaard et al., 2009). The highest detection rate (number of clicks detected by the T-POD per day) was seen in scans with a target frequency of $130 \mathrm{kHz}$, with declining detection rates in scans with other settings where the frequency of detected clicks was either less or greater than the target frequency in those scans. The T-POD was then set as shown in Table 1, with three scans/min to detect the high-frequency Heaviside's dolphin clicks (target frequency: $130 \mathrm{kHz}$; reference frequency: $90 \mathrm{kHz}$ ) and three scans set to allow for detection of other dolphin species with lower-frequency, nonNBHF clicks (target frequency: $50 \mathrm{kHz}$; reference frequency: $90 \mathrm{kHz}$ ) such as bottlenose dolphins (Philpott et al., 2007; Simon et al., 2010). Upon retrieval, data were downloaded and processed using the instrument-specific software (TPOD. exe, Version 8.24; train filter Version 4.1; www. chelonia.co.uk). The automated train detection function in the program filters out clicks arising at random from background noise, resulting in files containing only clicks in sequences (trains), which may include cetacean and boat sonar sources. From these filtered data, the TPOD.exe software designates various levels of probability of a click train being of cetacean origin (see Thomsen et al., 2005 , for further details). The two most reliable categories of cetacean click trains, "high" and "low" probability (as defined by the TPOD.exe software), were used for further analysis.

Table 1. Final T-POD settings; number of clicks logged was limited to 240/scan. "Ch" - Heaviside's dolphins; "Tt" bottlenose dolphins. Scans alternated between each set of settings, resulting in three scans each per minute for each setting. For an explanation of the setting parameters, see Todd et al. (2009) and Simon et al. (2010).

\begin{tabular}{lcc}
\hline & $\begin{array}{c}\text { To detect } \\
\text { Ch }\end{array}$ & $\begin{array}{c}\text { To detect } \\
\text { Tt/other spp. }\end{array}$ \\
\hline Target (A) frequency (kHz) & 130 & 50 \\
Reference (B) frequency (kHz) & 90 & 90 \\
Ratio A/B & 5 & 4 \\
A integration period & short & short \\
B integration period & long & long \\
Minimum intensity & 3 & 3 \\
\hline
\end{tabular}

Bottlenose dolphins (Tursiops truncatus) were also present in the study area and produce clicks which can be recorded by the T-POD. Clicks from this species are bimodal and have energy both in a lower (50 to $70 \mathrm{kHz}$ ) frequency range and around the same higher frequency as Heaviside's dolphins (Au, 1993; dos Santos \& Almada, 2003), which can make species distinction difficult. Simon et al. (2010) highlight the fact that on-axis clicks from bottlenose dolphins can have their peak energy at $100 \mathrm{kHz}$ or higher and thus presumably could be detected on T-PODs with "porpoise" settings (target filter at $130 \mathrm{kHz}$ ) but might fail to be detected by a T-POD with "dolphin" settings (where the target filter is set at $50 \mathrm{kHz}$ ). However, off-axis bottlenose dolphin clicks can have peak energy at around $50 \mathrm{kHz}$ and are therefore likely to be detected with "dolphin" settings. It is thus possible that the automatic export of high-frequency trains, expected to be of Heaviside's dolphin origin, could include some trains from other cetacean sources, most likely bottlenose dolphins in this case. To reduce the likelihood of this occurring, we further filtered our data by excluding time periods in which bottlenose dolphin-like clicks (50 to $70 \mathrm{kHz}$ ) were recorded. For data calculated per minute, any whole minutes of data in which bottlenose dolphin-like clicks were recorded, as well as the minute before and after that time, were 
removed (out of 21,288 Heaviside's dolphin trains, 315 [1.0\%] were removed). For calculations per hour, the entire hour was excluded from analysis if low-frequency clicks were recorded and ten or fewer high-frequency clicks were detected (out of $337 \mathrm{~h}$ of data, $45 \mathrm{~h}$ contained both bottlenose dolphin-like and Heaviside's dolphin clicks, of which $12 \mathrm{~h}[3.5 \%$ of total] were removed).

\section{Characteristics of Click Trains}

Data on Heaviside's dolphin click trains were exported from TPOD.exe to a spreadsheet for further analysis. Mean inter-click interval (ICI) was calculated for every Heaviside's dolphin click train individually and averaged for each hour of the day. Because the TPOD.exe click train identification software can occasionally include a click of non-cetacean origin at the beginning or end of a cetacean train, thereby generating a false value for ICI (N. J. Tregenza, pers. comm., January 2009), mean ICI was considered a more representative measurement than minimum ICI (MICI) (Carlström, 2005; Todd et al., 2009). Feeding-buzz ratio (FBR) has previously been used as an indicator of potential feeding behaviour for odontocetes (Todd et al., 2009). The terms feeding buzz or click burst have been used to describe the very fast click trains (i.e., with small ICI values) produced as cetaceans or bats approach and capture targets such as prey items (e.g., Goodson et al., 1988, 1994; Miller et al., 1995; Johnson et al., 2004, 2006, 2008; Akamatsu et al., 2005; Madsen et al., 2005; Melcón et al., 2007; Verfu $\beta$ et al., 2009). In the terminal phase of the approach of harbour porpoises to prey items, the ICI is first reduced from about $50 \mathrm{~ms}$ to intervals below $10 \mathrm{~ms}$ and is then kept short and constant at values between 1.4 and $1.6 \mathrm{~ms}$ (Verfu $\beta$ et al., 2009). In order to investigate diel patterns in the proportion of "fast" click trains from harbour porpoises, Carlström (2005) chose $10 \mathrm{~ms}$ as the value below which to define such trains, based on the shapes of the frequency distributions of MICI and on ICI of captive animals, which were recorded during different behaviours from other studies (Carlström, 2005, and references therein). For this study, we therefore chose to use ICI values below $10 \mathrm{~ms}$ as a possible indicator of feeding behaviour or target-locking. FBR values were calculated by dividing the number of click trains in each individual hour with a mean ICI of $<10 \mathrm{~ms}$ by the number with a mean ICI of $\geq 10 \mathrm{~ms}$, creating a ratio of fast, possibly feedingassociated click trains to all other trains (Todd et al., 2009). A high ratio would thus suggest more time spent producing buzz trains and therefore possibly engaging in feeding behaviour.

To investigate the diel pattern in mean ICI, a generalized linear model (GLM) was used to predict the mean ICI of a train as a function of a sinusoid curve with a period of $24 \mathrm{~h}$. A log link and gamma errors were used due to a right-skew in the distribution of mean ICI. The mean ICI of trains recorded within a short time of each other is unlikely to be fully independent, leading to the potential overestimation of the significance of diel patterns. We therefore reduced the impact of this autocorrelation by including the log-transformed mean ICI of the most recently recorded train as a time-lagged predictor variable in the model. To investigate diel patterns in FBR, each train was classified as a buzz train (mean ICI $<10 \mathrm{~ms}$ ) or not (mean ICI $\geq 10 \mathrm{~ms}$ ), following the same analytical procedure as in Todd et al. (2009) but using mean ICI instead of MICI. A GLM with binomial errors and a logit link was used to predict the probability that any given click train was a buzz train, as a function of a 24-h sinusoid, and whether or not the previous train was a buzz train. These probabilities were converted to ratios using FBR $=$ probability $/(1-$ probability $)$ for plotting.

\section{Temporal Patterns of Habitat Use}

To describe patterns of habitat use over the deployment period, T-POD data were processed as the number of Detection-Positive Minutes per hour $\left(\right.$ DPM.h $\left.{ }^{-1}\right)$ for every complete hour for which the unit was logging (see data filtering protocol above regarding detection of possible bottlenose dolphin clicks). A Gaussian linear model was fitted to arcsine-transformed DPM. $\mathrm{h}^{-1}$ data from the T-POD. The diel pattern was modeled as a sinusoid of the 24-h period, and the DPM.h ${ }^{-1}$ from the previous hour was included to account for the autocorrelation inherent in this type of dataset. All statistical analyses were carried out using the program $R$ (R Development Core Team, 2010). The significance of terms in linear models and GLMs was tested by comparing AICs before and after their elimination from the model (Crawley, 2006).

\section{Results}

Almost all the detections on the T-POD were made in the higher-frequency (90 to $130 \mathrm{kHz}$ ) scans, with very occasional detections in the lower-frequency scans (after exclusion of 78 click trains, containing 2,311 "bottlenose dolphin" clicks, 20,973 click trains, containing 428,866 clicks, remained for analysis). Thus, the exclusion of the time periods in which lower-frequency detections were made is unlikely to have affected general patterns in the data. Anecdotal information from tour operators and the sightings data several operators have collected over the past 5 y suggest that there are only two odontocete species sighted with any regularity in the region: Heaviside's dolphins 
and bottlenose dolphins (Elwen \& Leeney, 2008). Boat-based photo-identification surveys carried out by SE and RHL over a 2-mo period within which the T-POD data were collected (22 May to 28 July 2008) confirm this assumption, and Heaviside's dolphins were by far the most regularly encountered and numerous of the two species (Table 2). No other cetaceans with NBHF click type are known to occur in the area; thus, after filtering of the data as described above, all remaining clicks in the higher-frequency scans have been assumed to be produced by Heaviside's dolphins.

Table 2. Number of sightings (and number of animals) made by the research team from both research cruises for photoidentification data collection ( 26 cruises; $152 \mathrm{~h}$ ) and on tour boats ( 6 trips; $21 \mathrm{~h}$ ); ranges indicate the sums of minimum and maximum group size counts. Number of individuals represents the sum over all encounters rather than number of unique individuals.

\begin{tabular}{lc}
\hline Species & $\begin{array}{c}\text { N encounters } \\
\text { (N individuals) }\end{array}$ \\
\hline Heaviside's dolphin & $168(1,061-1,515)$ \\
Bottlenose dolphin & $30(259-353)$ \\
Killer whale (Orcinus orca) & $1(2)$ \\
Humpback whale (Megaptera & $9(16)$ \\
novaeangliae) & $1(1)$ \\
Southern right whale (Eubalaena & \\
australis) & \\
\hline
\end{tabular}

Having excluded lower-frequency click detection periods, the remaining dataset was analysed to describe Heaviside's dolphin echolocation behaviour. Mean ICI ranged between 0.82 and $333 \mathrm{~ms}$ (median of 19.6; inter-quartile range between 13.9 and 34.5), although only ten trains had mean ICI values above $167 \mathrm{~ms}$. There was a distinct diel pattern in mean ICI, with higher values during daylight hours than at night (Figure 2a) - that is, slower click trains during the day and faster click trains at night. Both the diel sinusoid $(\triangle \mathrm{AIC}$ on removal from the full model $=+872.00)$ and the lagged component $(\triangle \mathrm{AIC}=+4,115.70)$ contributed highly significantly to the prediction of the mean ICI of a train. FBR ranged between 0.04 and 0.22 , but there was no apparent diel pattern in the data (Figure 2b). The lagged component contributed significantly to the prediction of FBR $(\triangle \mathrm{AIC}=+32,288.06)$, but the diel sinusoid did not $(\triangle \mathrm{AIC}=-0.85)$. Pulse repetition frequency $(\mathrm{PRF})$ ranged between 3 and 1,219 clicks/s, with most trains having PRFs below 100 clicks/s (Figure 3). A small secondary peak in PRF, which corresponds with fast "buzz" trains, is visible at 500 to 550 clicks/s. A diel pattern was apparent in the a.

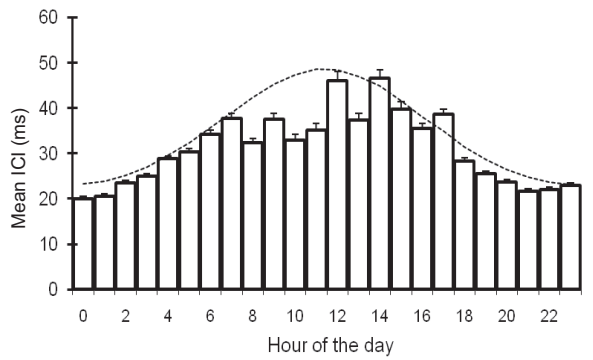

b.

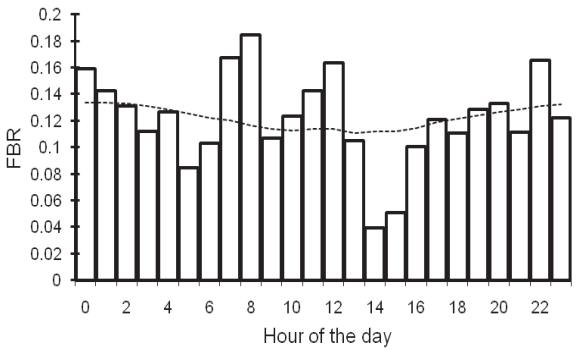

Figure 2. (a) Hourly mean inter-click intervals $(\mathrm{ICI})+$ s.e. per train and (b) hourly mean feeding buzz ratio (FBR) (number of trains with mean ICI $<10 \mathrm{~ms} /$ number of trains with mean ICI $\geq 10 \mathrm{~ms}$ ); hour 0 refers to the hour between midnight and $0100 \mathrm{~h}$; dotted lines represent the fitted sinusoid curve for each model.

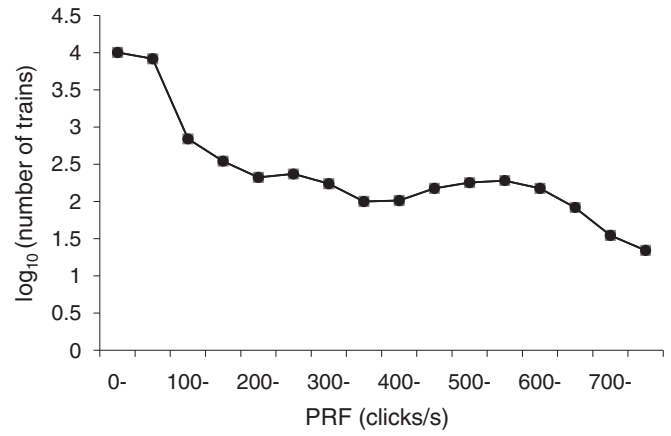

Figure 3. Distribution of PRF values (in 50 clicks/s bins) for all Heaviside's dolphin click trains detected by the T-POD on a $\log _{10}$ scale

presence of Heaviside's dolphins at Pelican Point, measured as DPM.h. ${ }^{-1}$ (Figure 4). Detections were considerably lower between $\sim 0600$ and $\sim 1600 \mathrm{~h}$ than in the evening or during the night. Both the autoregressive term ( $\triangle \mathrm{AIC}=+241.12)$ and the diel sinusoid $(\triangle \mathrm{AIC}=+15.67)$ contributed significantly to the prediction of DPM. ${ }^{-1}$ from the T-POD data. 


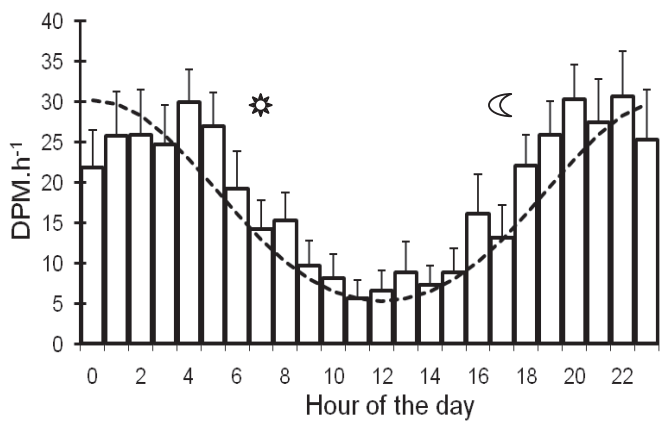

Figure 4. Diel patterns in the detection of Heaviside's dolphin sounds at one location in Walvis Bay, Namibia, monitored by a T-POD; mean (+ s.e.) hourly detection rates (DPM. $\left.^{-1}\right), 28$ June to 3 July and 16 to 25 July 2008 ( $n=14$ for most hours; minimum $n=8)$. Average sunrise $(0630 \mathrm{~h}$ ) and sunset $(1723 \mathrm{~h})$ times over the T-POD deployment periods are indicated by symbols. The dotted line represents the fitted sinusoid curve. Hour 0 refers to the period between midnight and $0100 \mathrm{~h}$.

\section{Discussion}

This study reports on the first use of the T-POD to monitor the vocalizations of Heaviside's dolphins. Although based on a relatively brief period of data, we detected a large number of vocalizations at a detection rate (DPM.h. $\left.\mathrm{h}^{-1}\right)$ up to one order of magnitude higher than that detected in a similar trialing study of the use of T-PODs on Hector's dolphins (Rayment et al., 2009b). Comparative information relating acoustic to behavioural data is limited for congeneric dolphin species, thus much of the following discussion is interpreted based on more detailed studies of the acoustically similar Phocoenids.

T-POD detection rates showed a distinct pattern over the 14-d sampling period. DPM. $\mathrm{h}^{-1}$ was high overnight, between 2000 and $0600 \mathrm{~h}$, and it dropped off during daylight hours, reaching the lowest levels around midday. Visual observations made during concurrent boat surveys, run in the area between $\sim 0730$ and $1300 \mathrm{~h}$, documented a decrease in Heaviside's dolphin abundance in the late mornings, suggesting that the reduced acoustic detections at midday are due to a reduction in dolphin presence at this site rather than changes in vocalization frequency only. Observations in the late afternoon and evening, when the SAM data suggest that we would have seen an increase in numbers again, were not available as strong winds prohibit boat-based work and tour boats do not operate (Elwen \& Leeney, 2008).

Click rates were comparable with those reported for Heaviside's dolphins (ICIs of 2 to 113 ms; Morisaka et al., 2011) and harbour porpoises (MICIs up to $120 \mathrm{~ms}$; Carlström, 2005). It is possible that the very few click trains with mean ICI values above $167 \mathrm{~ms}$ represent false positive detections. Click trains from Heaviside's dolphins at Pelican Point displayed higher mean ICIs during the daytime than at night, indicating that clicks were produced at faster rates during the night. Click trains with lower ICI values have been associated with the investigation of objects at close range and feeding (Akamatsu et al., 2005; Carlström, 2005; Verfu $\beta$ et al., 2009). In a study of harbour porpoise click behaviour in Scotland, Carlström (2005) reported a peak in mean MICI per train at night and suggested that this slower click rate indicated that porpoises used their echolocation to explore their surroundings at greater distances during the night than in the day. In contrast, our findings document higher mean ICI during daylight hours and lower values at night. The approximately sinusoidal pattern in mean ICI data suggests a diel pattern which may be linked to daylight or patterns in prey behaviour. The considerable level of boat traffic, and thus underwater noise, around our study area during daylight hours and especially until around midday may also influence echolocation behaviour at this site.

Photo-identification surveys for this species throughout Walvis Bay have provided a population estimate of several hundred individuals, with group sizes of between one and eight individuals (Elwen \& Leeney, 2009). The Pelican Point aggregation area where our data were collected is the only site of predictable Heaviside's dolphin abundance for tens of kilometres in each direction, and at least one dolphin was observed there during each visit to the area by the research boat (over 100 visits between 2008 and 2010; Elwen \& Leeney, unpub. data), which might suggest that this habitat is linked to feeding activity. Todd et al. (2009) used T-PODs to monitor echolocation behaviour around an offshore gas installation in the North Sea and found that median MICI values for harbor porpoises were significantly lower at night than during the three other predefined diel phases, a similar pattern to the findings of our study. They suggested that their findings indicated a greater proportion of echolocation behaviour allocated towards target-locking and feeding activity at night; however, this suggestion was supported by a significantly higher FBR during that time. A diel pattern in FBR might be expected if Heaviside's dolphins were feeding at Pelican Point on prey items which themselves exhibited diel patterns in availability. Our data showed no diel pattern in FBR despite the observed diel pattern in mean ICI, suggesting that the latter is not connected to feeding behaviour. Alternatively, a higher threshold in PRF (e.g., trains with click rates $>500 \mathrm{~s}^{-1}$ ) 
may be more appropriate for the calculation of FBR in Heaviside's dolphins. FBR varied considerably from one hour to the next during the daytime (Figure $2 b$ ), which may reflect a complex diel pattern with multiple peaks in feeding or sampling error among the smaller numbers of trains detected during daylight hours (Figure 4). Heaviside's dolphins may thus be feeding at this site, but on prey items which have no pattern in availability. Alternatively, Heaviside's dolphins may use buzz trains for purposes other than or in addition to feeding such as for communication.

The apparent diel pattern in habitat use at Pelican Point is entirely opposite to that seen in the southern part of the species' range in South African waters. Observations made from shore (Elwen et al., 2009) and satellite telemetry (Elwen et al., 2006) showed that Heaviside's dolphins in South Africa were closest to shore during the mornings, between 0600 and $1200 \mathrm{~h}$, and were furthest from shore (up to $20 \mathrm{~km}$ ) at night. The clear diel onshore-offshore migration pattern observed in South Africa is thought to be associated with feeding nocturnally on vertically migrating demersal prey, most likely juvenile shallow water hake (Merluccius capensis) (Sekiguchi et al., 1992; Elwen et al., 2010). While the short duration of the current dataset limits the conclusions that can be drawn from these observations, it may be that Heaviside's dolphins at Pelican Point are feeding on prey with different diel patterns to those in South Africa, or they may be engaging in nonfeeding behaviours at this site. It is currently unknown where the dolphins using Pelican Point go when not present at this site. This species has been sighted at over $80 \mathrm{~km}$ from the coast (Findlay et al., 1992), and a recent aerial survey reported Heaviside's dolphins along several kilometers of the coast, south of Walvis Bay (Leeney, unpub. data). It is thus possible that the population disperses throughout this area when not aggregated at Pelican Point and may use offshore waters as well. The high levels of daytime boat traffic due to marine wildlife-watching tourism activities in Walvis Bay may also affect patterns of habitat use by Heaviside's dolphins at Pelican Point. Given that populations of this species appear to have small home ranges of $\sim 50$ to $80 \mathrm{~km}$ alongshore (Elwen et al., 2006), Heaviside's dolphins utilizing Pelican Point may be particularly susceptible to stressors specific to this region. Clearly, further detailed work investigating the acoustic behaviour, habitat use patterns, and diet of Heaviside's dolphins is needed to fully understand the ecology of this species at this site and to ensure its protection. Ongoing SAM data collection at this and several other sites will, in the future, provide insight into longer-term temporal patterns of habitat use by
Heaviside's dolphins in Namibian waters (Elwen \& Leeney, 2009).

Although the SAM dataset is small, it nonetheless highlights the value of static acoustic monitoring in this environment and for aroundthe-clock collection of data on habitat use. The T-POD proved an appropriate tool for monitoring habitat use by Heaviside's dolphins, and the initial data suggest distinct diel patterns of vocalization activity, potentially indicative of abundance at this specific site. This study documents the first known use of a SAM tool to assess temporal patterns in Heaviside's dolphin echolocation click behaviour.

\section{Acknowledgments}

The Namibian Dolphin Project is funded by the British Ecological Society, the Mohammed bin Zayed Species Conservation Fund, NACOMA, the Nedbank Namibia Go Green Fund, and the Rufford Small Grants Foundation, in collaboration with the Namibian Nature Foundation and the Namibian Ministry for Fisheries and Marine Resources. Research was carried out under a scientific research permit issued to $\mathrm{S}$. Elwen and R. Leeney by the Namibian Ministry of Fisheries and Marine Resources. We are indebted to the marine tour operators of Walvis Bay for their support, especially I. Venter of Pelican Tours, Catamaran Charters, and Mola Mola Tours for the loan of the research vessel Pedro and to Dr S. Northridge of the Sea Mammal Research Unit, University of St Andrews, for the loan of the T-POD used in this study. Special thanks to R. Braby, C. Brown, J. Eduardo, P. Hoare, J. \& B. Paterson, H. Skrypzeck, N. J. C. Tregenza, and K. \& G. Wearne. This manuscript has been improved considerably by comments from the editor and two anonymous referees. This paper is dedicated to the memory of Keith Wearne, for his tireless conservation efforts for the Walvis Bay area and for his help and support.

\section{Literature Cited}

Akamatsu, T., Wang, D., Wang, K., \& Naito, Y. (2005). Biosonar behaviour of free ranging porpoises. Proceedings of the Royal Society B: Biological Sciences, 272, 797-801. doi:10.1098/rspb.2004.3024

Akamatsu, T., Nakamura, K., Kawabe, R., Furukawa, S., Murata, H., Kawakubo, A., \& Komaba, M. (2010). Seasonal and diurnal presence of finless porpoises at a corridor to the ocean from their habitat. Marine Biology, 157, 1879-1887. doi: 10.1007/s00227-010-1459-8

$\mathrm{Au}$, W. W. L. (1993). The sonar of dolphins. New York: Springer-Verlag. 
Best, P. B., \& Abernethy, R. B. (1994). Heaviside's dolphin, Cephalorhynchus heavisidii (Gray, 1828). In S. H. Ridgway \& R. Harrison (Eds.), The handbook of marine mammals (Vol. 6, pp. 289-310, 415-416). New York: Academic Press.

Carlström, J. (2005). Diel variation in echolocation behavior of wild harbor porpoises. Marine Mammal Science, 21, 1-12. doi:10.1111/j.1748-7692.2005.tb01204.x

Clausen, K. T., Wahlberg, M., Beedholm, K., DeRuiter, S., \& Madsen, P. T. (2010). Click communication in harbour porpoises Phocoena phocoena. Bioacoustics: The International Journal of Animal Sound and Its Recording, 20, 1-28.

Crawley, M. J. (2006). The R book. Chichester, UK: John Wiley \& Sons Ltd.

Dawson, S. M. (1988). The high frequency sounds of freeranging Hector's dolphin, Cephalorhynchus hectori. Report of the International Whaling Commission, 9, 339-341.

Dawson, S. M. (1991). Incidental catch of Hector's dolphin in inshore gill nets. Marine Mammal Science, 7, 283295. doi:10.1111/j.1748-7692.1991.tb00103.x

Dawson, S. M., \& Thorpe, C. W. (1990). A quantitative analysis of the sounds of Hector's dolphin. Ethology, 86, 131-145. doi:10.1111/j.1439-0310.1990.tb00424.x

dos Santos, M. E., \& Almada, V. C. (2004). A case for passive sonar: Analysis of click train production patterns by bottlenose dolphins. In J. A. Thomas, C. F. Moss, \& M. Vater (Eds.), Echolocation in bats and dolphins (pp. 400-403). Chicago: University of Chicago Press.

Elwen, S. H., \& Leeney, R. H. (2008). The Namibian Dolphin Project: Ecology \& conservation of coastal dolphins in Namibia (Pilot Study Report). 33 pp.

Elwen, S. H., \& Leeney, R. H. (2009). The Namibian Dolphin Project: Ecology \& conservation of coastal dolphins in Namibia. 25 pp. \& one appendix.

Elwen, S. H., \& Leeney, R. H. (2010). Injury and subsequent healing of a propeller strike injury to a Heaviside's dolphin (Cephalorhynchus heavisidii). Aquatic Mammals, 36(4), 382-387. doi: 10.1578/AM.36.4.2010.382

Elwen, S. H., Reeb, D., Thornton, M., \& Best, P. B. (2009). A population estimate of Heaviside's dolphins, Cephalorhynchus heavisidii, at the southern end of their range. Marine Mammal Science, 25, 107-124. doi: 10.1111/j.1748-7692.2008.00246.x

Elwen, S., Thornton, M., Reeb, D., \& Best, P. B. (2010). Near-shore distribution of Heaviside's (Cephalorhynchus heavisidii) and dusky dolphins (Lagenorhynchus obscurus) at the southern limit of their range in South Africa. African Zoology, 45(1), 78-91. doi: $10.3377 / 004.045 .0103$

Elwen, S. H., Meÿer, M. A., Best, P. B., Kotze, P. G. H., Thornton, M., \& Swanson, S. (2006). Range and movements of female Heaviside's dolphins Cephalorhynchus heavisidii as determined by satellite telemetry. Journal of Mammalogy, 87, 866-877. doi:10.1644/05-MAMMA-307R2.1
Findlay, K. P., Best, P. B., Ross, G. J. B., \& Cockcroft, V. G. (1992). The distribution of small odontocete cetaceans off the coasts of South Africa and Namibia. South African Journal of Marine Science, 12, 237-270.

Goodson, A. D., \& Sturtivant, C. R. (1996). Sonar characteristics of the harbour porpoise (Phocoena phocoena): Source levels and spectrum. ICES Journal of Marine Science, 53(2), 465-472. doi:10.1006/jmsc.1996.0066

Goodson, A. D., Klinowska, M., \& Bloom, P. R. S. (1994). Enhancing the acoustic detectability of gillnets. In W. F. Perrin, G. P. Donovan, \& J. Barlow (Eds.), Gillnets and cetaceans (pp. 585-595). Cambridge, UK: Black Bear Press.

Goodson, A. D., Klinowska, M., \& Morris, R. (1988). Interpreting the acoustic pulse emissions of a wild bottlenose dolphin (Tursiops truncatus). Aquatic Mammals, 14(1), 7-12.

Götz, T., Antunes, R., \& Heinrich, S. (2010). Echolocation clicksoffree-ranging Chileandolphins (Cephalorhynchus eutropia). The Journal of the Acoustical Society of America, 128, 563-566. doi: 10.1121/1.3353078

Iñiguez, M. A., Hevia, M., Gasparrou, C., Tomsin, A. L., \& Secchi, E. R. (2003). Preliminary estimate of incidental mortality of Commerson's dolphins (Cephalorhynchus commersonii) in an artisanal setnet fishery in La Angelina beach and Ría Gallegos, Santa Cruz, Argentina. Latin American Journal of Aquatic Mammals, 2, 87-94.

Johnson, M., Hickmott, L. S., Soto, N. A., \& Madsen, P. T. (2008). Echolocation behaviour adapted to prey in foraging Blainville's beaked whale (Mesoplodon densirostris). Proceedings of the Royal Society of London B: Biological Sciences, 275, 133-139. doi: 10.1098/ rspb.2007.1190

Johnson, M., Madsen, P. T., Zimmer, W. M. X., Aguilar de Soto, N., \& Tyack, P. L. (2004). Beaked whales echolocate on prey. Proceedings of the Royal Society of London B: Biological Sciences, 271(Supp. 6), S383S386. doi:10.1098/rsbl.2004.0208

Johnson, M., Madsen, P. T., Zimmer, W. M. X., Aguilar de Soto, N., \& Tyack, P. L. (2006). Foraging Blainville's beaked whales (Mesoplodon densirostris) produce distinct click types matched to different phases of echolocation. Journal of Experimental Biology, 209, 50385050. doi:10.1242/jeb.02596

Kamminga, C., \& Wiersma, H. (1982). Investigations on cetacean sonar. V. The true nature of the sonar sound of Cephalorhynchus commersonii. Aquatic Mammals, 9(3), 95-104.

Kimura, S., Akamatsu, T., Li, S., Dong, S., Dong, L., Wang, K., Wang, D., et al. (2010). Density estimation of Yangtze finless porpoises using passive acoustic sensors and automated click train detection. The Journal of the Acoustical Society of America, 128(3), 1435-1445. doi: 10.1121/1.3442574

King, R., \& Brooks, S. P. (2004). Bayesian analysis of the Hector's dolphin data. Animal Biodiversity and Conservation, 27, 343-354. 
Kyhn, L. A., Jensen, F. H., Beedholm, K., Tougaard, J., Hansen, M., \& Madsen, P. T. (2010). Echolocation in sympatric Peale's dolphins (Lagenorhynchus australis) and Commerson's dolphins (Cephalorhynchus commersonii) producing narrow-band high-frequency clicks. Journal of Experimental Biology, 213, 1940-1949. doi:10.1242/jeb.042440

Kyhn, L. A., Tougaard, J., Teilmann, J., Wahlberg, M., Jørgensen, P. B., \& Bech, N. I. (2008). Harbour porpoise (Phocoena phocoena) static acoustic monitoring: Laboratory detection thresholds of T-PODs are reflected in field sensitivity. Journal of the Marine Biological Association of the United Kingdom, 88(6), 1085-1091. doi:10.1017/S0025315408000416

Kyhn, L. A., Tougaard, J., Jensen, F., Wahlberg, M., Stone, G., Yoshinaga, A., Beedholm, K., et al. (2009). Feeding at a high pitch: Source parameters of narrow band, highfrequency clicks from echolocating off-shore hourglass dolphins and coastal Hector's dolphins. The Journal of the Acoustical Society of America, 125, 1783-1791. doi:10.1121/1.3075600

Leeney, R. H., \& Tregenza, N. J. C. (2006). Proceedings of the workshop, Static Acoustic Monitoring of Cetaceans, held at the 20th Annual Meeting of the European Cetacean Society, Gdynia, Poland, 2nd April 2006. ECS Newsletter, 46(Special Issue).

Leeney, R. H., Berrow, S., McGrath, D., O'Brien, J., Cosgrove, R., \& Godley, B. J. (2007). Effects of pingers on the behaviour of bottlenose dolphins. Journal of the Marine Biological Association of the United Kingdom, 87(1), 129-133. doi: 10.1017/S0025315407054677

Madsen, P. T., Johnson, M., Aguilar de Soto, N., Zimmer, W. M. X., \& Tyack, P. L. (2005). Biosonar performance of foraging beaked whales (Mesoplodon densirostris). Journal of Experimental Biology, 208, 181-194. doi:10.1242/jeb.01327

Marques, T. A., Thomas, L., Ward, J., Demarzio, N., \& Tyack, P. L. (2009). Estimating cetacean population density using fixed passive acoustic sensors: An example with Blainville's beaked whales. The Journal of the Acoustical Society of America, 125(4), 1982-1994. doi:10.1121/1.3089590

Melcón, M. L., Denzinger, A., \& Schnitzler, H-U. (2007). Aerial hawking and landing: Approach behaviour in Natterer's bats, Myotis nattereri (Kuhl 1818). Journal of Experimental Biology, 210, 4457-4464. doi:10.1242/ jeb.007435

Mellinger, D. K., Stafford, K. M., Moore, S. E., Dziak, R. P., \& Matsumoto, H. (2007). An overview of fixed passive acoustic observation methods for cetaceans. Oceanography, 20(4), 36-45.

Miller, L. A., Pristed, J., Møhl, B., \& Surlykke, A. (1995). The click-sounds of narwhals (Monodon monoceros) in Inglefield Bay, Northwest Greenland. Marine Mammal Science, 11, 491-502. doi:10.1111/j.1748-7692.1995. tb00672.x

Morisaka, T., \& Connor, R. C. (2007). Predation by killer whales (Orcinus orca) and the evolution of whistle loss and narrow-band high frequency clicks in odontocetes. Journal of Evolutionary Biology, 20, 1439-1458. doi:10.1111/j.1420-9101.2007.01336.x

Morisaka, T., Karczmarski, L., Akamatsu, T., Sakai, M., Dawson, S., \& Thornton, M. (2011). Echolocation signals of Heaviside's dolphins (Cephalorhynchus heavisidii). The Journal of the Acoustical Society of America, 129(1), 449-457. doi:10.1121/1.3519401

Philpott, E., Englund, A., Ingram, S., \& Rogan, E. (2007). Using T-PODs to investigate the echolocation of coastal bottlenose dolphins. Journal of the Marine Biological Association of the United Kingdom, 87(1), 213-221. doi: 10.1017/S002531540705494X

R Development Core Team. (2010). R: A language and environment for statistical computing. Vienna, Austria: R Foundation for Statistical Computing (ISBN 3-90005107-0; www.R-project.org).

Rayment, W., Dawson, S., \& Slooten, L. (2009a). Trialling an automated passive acoustic detector (T-POD) with Hector's dolphins (Cephalorhynchus hectori). Journal of the Marine Biological Association of the United Kingdom, 89(5), 1015-1022. doi:10.1017/S0025315409003129

Rayment, W., Dawson, S., \& Slooten, L. (2009b). Use of T-PODs for acoustic monitoring of Cephalorhynchus dolphins: A case study with Hector's dolphins in a marine protected area. Endangered Species Research, 10, 333-339. doi: 10.3354/esr00189

Sekiguchi, K., Klages, N. T. W., \& Best, P. B. (1992). Comparative analysis of the diets of smaller odontocete cetaceans along the coast of southern Africa. South African Journal of Marine Science, 12(1), 843-861.

Simon, M., Nuuttila, H., Reyes-Zamudio, M. M., Ugarte, F., Verfuß, U., \& Evans, P. G. H. (2010). Passive acoustic monitoring of bottlenose dolphin and harbour porpoise, in Cardigan Bay, Wales, with implications for habitat use and partitioning. Journal of the Marine Biological Association of the United Kingdom, 90(8), 1539-1545. doi:10.1017/S0025315409991226

Thomsen, F., Van Elk, N., Brock, V., \& Werner, P. (2005). On the performance of automated porpoise-click detectors in experiments with captive harbour porpoises (Phocoena phocoena L.). The Journal of the Acoustical Society of America, 118, 37-40. doi:10.1121/1.1937347

Todd, V. L. G., Pearse, W. D., Tregenza, N. C., Lepper, P. A., \& Todd, I. B. (2009). Diel echolocation activity of harbour porpoises (Phocoena phocoena) around North Sea offshore gas installations. ICES Journal of Marine Science, 66, 734-745. doi: 10.1093/icesjms/fsp035

Tougaard, J., \& Kyhn, L. A. (2010). Echolocation sounds of hourglass dolphins (Lagenorhynchus cruciger) are similar to the narrow band high-frequency echolocation sounds of the dolphin genus Cephalorhynchus. Marine Mammal Science, 26(1), 239-245. doi: 10.1111/j.17487692.2009.00307.x

Tougaard, J., Carstensen, J., Teilmann, J., Skov, H., \& Rasmussen, P. (2009). Pile driving zone of responsiveness extends beyond $20 \mathrm{~km}$ for harbor porpoises (Phocoena 
phocoena [L.]). The Journal of the Acoustical Society of America, 126(1), 11-14. doi: 10.1121/1.3132523

Tougaard, J., Rosager, P., Amundin, M., Larsen, F., Rye, J., \& Teilmann, J. (2006). Detection function of T-PODs and estimation of porpoise densities. In R. H. Leeney \& N. J. C. Tregenza (Eds.), Proceedings of the workshop, Static Acoustic Monitoring of Cetaceans, held at the 20th Annual Meeting of the European Cetacean Society, Gdynia, Poland, 2nd April 2006. ECS Newsletter, 46(Special Issue).

Van Parijs, S. M., Clark, C. W., Sousa-Lima, R. S., Parks, S. E., Rankin, S., Risch, D., \& Van Opzeeland, I. C. (2009). Management and research applications of realtime and archival passive acoustic sensors over varying temporal and spatial scales. Marine Ecology Progress Series, 395, 21-36. doi: 10.3354/meps08123

Verfuß, U., Miller, L. A., \& Schnitzler H-U. (2005). Spatial orientation in echolocating harbour porpoises (Phocoena phocoena). Journal of Experimental Biology, 208, 33853394. doi:10.1242/jeb.01786

Verfuß, U. K., Miller, L. A., Pilz, P. K. D., \& Schnitzler, H-U. (2009). Echolocation by two foraging harbour porpoises (Phocoena phocoena). Journal of Experimental Biology, 212, 823-834. doi:10.1242/jeb.022137

Verfuß, U., Honnef, C. G., Meding, A., Dähne, M., Mundry, R., \& Benke, H. (2007). Geographical and seasonal variation of harbour porpoise (Phocoena phocoena) presence in the German Baltic Sea revealed by passive acoustic monitoring. Journal of the Marine Biological Association of the United Kingdom, 87(1), 165-176. doi: 10.1017/S0025315407054938

Watkins, W. A., Schevill, W. E., \& Best, P. B. (1977). Underwater sounds of Cephalorhynchus heavisidii (Mammalia: Cetacea). Journal of Mammalogy, 58, 316320. doi:10.2307/1379330

Whitehead, H. (2009). Estimating abundance from onedimensional passive acoustic surveys. Journal of Wildlife Management, 73(6), 1000-1009. doi: 10.2193/2008-303. doi:10.2193/2008-303 